\title{
THE USE OF THE IMAGE ANALYSIS METHOD FOR THE SEGREGATION OF SHREDDED WASTE IN AN AIR CLASSIFIER
}

\author{
Irmina ZAGAJ $^{1}$, Roman ULBRICH \\ Opole University of Technology, Faculty of Mechanical Engineering, \\ Department of Environmental Engineering, Opole, Poland
}

\begin{abstract}
Segregation of shredded waste is one of the technologies of waste management, along with issues related to manual segregation, while nowadays it starts to be associated with pneumatic classification. This paper discusses the use of an air classifier and image analysis techniques for the purposes of evaluation of segregation of shredded waste. This type of air classifier plays an important role due to the efficiency of the device and the characteristics of segregation. The authors report the results of research into image analysis of segregation of shredded waste on the basis of the use of image analysis.
\end{abstract}

Keywords: segregation, shredded waste, air classifier, image analysis method

\section{INTRODUCTION}

Reducing the volume of waste dumped into landfills, as well as the re-use of raw materials offers one of the most promising solutions of waste management technology [7, 9]. Given such equipment as air classifiers, we can obtain technological solutions of waste management. They offer the opportunity of waste segregation in a mechanical way, as it can help to separate flammable material and ballast from the waste stream. The distribution systems using air classifiers are based on the utilization of the variable properties of waste $[10$,

\footnotetext{
${ }^{1}$ Corresponding author: Opole University of Technology, Faculty of Mechanical Engineering, Department of Environmental Engineering, ul. St. Mikołajczyka 5, 45-271 Opole, Poland; e-mail: I.Zagaj@o2.pl, tel. +48774498390
} 
11]. Typically, air classifiers consist of a single unit or form a part of the processing plants utilized for segregation of shredded waste.

The principle of operation of an air classifier is based the use of the difference in the drop velocity of air containing waste [2, 4]. Automatically controlled air flow with an adjustable velocity is driven against a stream of waste.

The classification of air classifiers depends on the direction of air flow, and the schematic representation of the separation of waste used in some models is presented in Fig. 1.

Segregation is assumed to be a phenomenon involving two-phase flow gas-solid flow and there is a possibility of describing it using image analysis.

a)

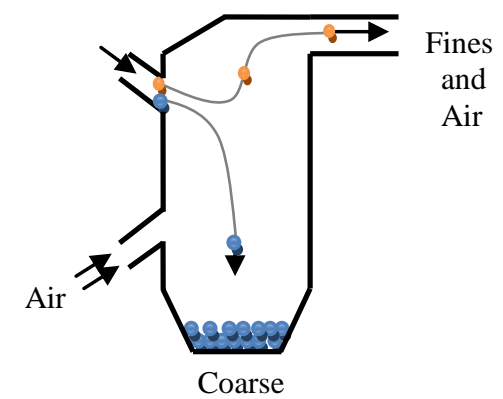

c)

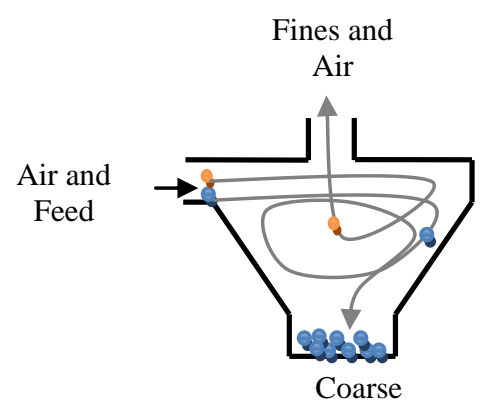

b)

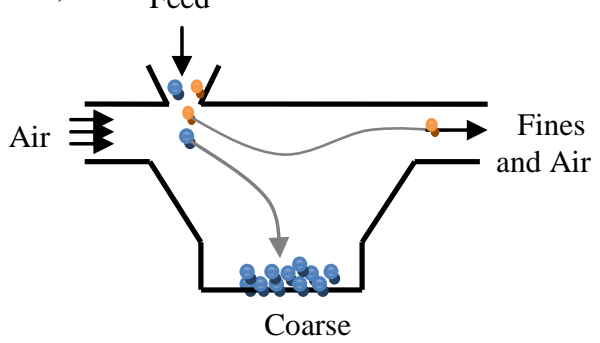

d)

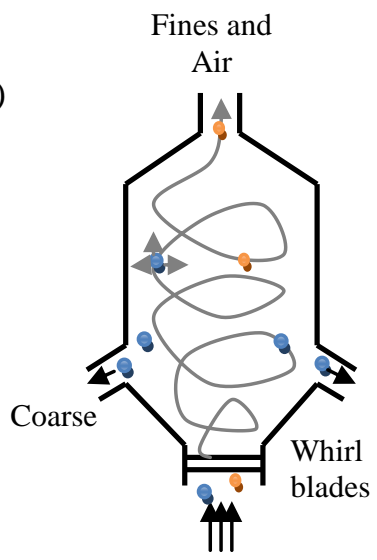

Fig. 1. Model of an air classifier a) vertical, b) horizontal, c) counterflow centrifugal, d) crossflow [5] 


\section{IMAGE ANALYSIS METHOD IN WASTE MANAGEMENT}

The method of image analysis involves a wide range of issues related to waste management. Equipment used for waste segregation, as well as the process of waste separation can involve the use of visual techniques. The objective in this process is to obtain a picture of the analyzed phenomenon, which can be applied in the description of the properties of waste segregation.

The image analysis method used in the research regarding segregation of waste enabled the authors to specify the velocity field and movement of segregated waste. As a result of an appropriate selection of operating parameters it was possible to represent the movement of shredded waste in the air classifier. As a result of visual measurements, it is also possible to:

- secure the proper operation of the air classifier equipment for waste segregation,

- develop a methodology for the separation of shredded waste behind the shredder,

- find the kinetic properties of shredded waste in the air classifier.

An important consideration during the segregation of shredded waste is associated with ensuring the relative velocity of the air flow as it affects their place of waste descent behind the shredder. In this respect, digital imaging anemometry (Digital Particle Image Velocimetry - DPIV) finds its place in the analysis of the velocity of vector fields and in illustrating the direction of displacement of the shredded waste.

The main task in this method involves determination of the displacement between two registered images of segregated waste in the form of monochrome bitmaps, as presented in Fig. 2. On the basis of displacement and determined velocity vectors, it is possible to classify bitmaps into sections taking into account the scale factor and the interval between the registrations of two segregation images $[3,8,12]$ form. Fast Fourier Transform (FFT) is applied to find the displacement of the section of the second segregation image in relation to the first segregation image, which can be subsequently used to establish the connection function of segregated waste. Fast Fourier Transform is the algorithm used for computing discrete Fourier Transform (DFT), and is expressed by formulae $[6,8]$ :

$$
F(i, k)=\beta_{0} \sum_{m=0}^{M-1} \sum_{n=0}^{N-1} 0(m, n) \exp \left(\frac{-j 2 \pi m i}{M}\right) \exp \left(\frac{-j 2 \pi n k}{N}\right)
$$

for $i=0,1, \ldots, M-1 ; k=0,1, \ldots, N-1$

where: 


$$
O(m, n)=\beta_{F} \sum_{i=0}^{M-1} \sum_{k=0}^{N-1} F(i, k)_{0} \exp \left(\frac{j 2 \pi m i}{M}\right) \exp \left(\frac{j 2 \pi n k}{N}\right)
$$

for $m=0,1, \ldots, M-1 ; n=0,1, \ldots, N-1$

$$
\beta_{\mathrm{O}} \cdot \beta_{\mathrm{F}}=\frac{1}{\mathrm{M} \cdot \mathrm{N}}
$$

a)

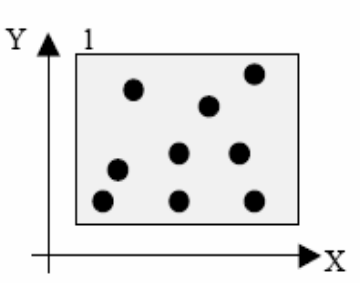

b)

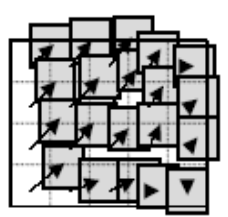

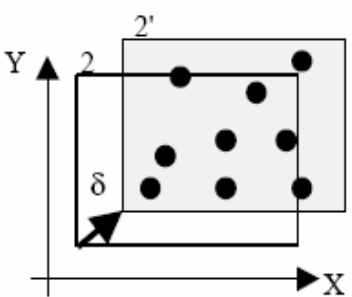

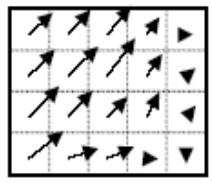

Fig. 2. Visualization of vector velocity fields using digital imaging anemometry [8]:

a) 1 - section of image 1,2 - section of image 2,2' - section of image 1 found in image $2, \delta$ - displacement of section 2 ' in relation to image $1, \mathrm{~b}$ ) transformation of displacement vectors into velocity fields

The description of shredded waste segregation involves the need to be aware of the time between the registration of two subsequent segregation images and the scale factor [1]. In this study, the interval between registered images of segregation was directly relative to camera resolution and the adopted frequency scale factor was based on the width of the zone of waste collection. The visualization of vector fields which define the velocity of segregation of shredded waste observation was undertaken with the use of the DPIV software [8].

\section{EXPERIMENTAL SETUP AND TECHNIQUE}

An experimental setup was designed and built in order to carry out research into waste segregation. The diagram of the installation in presented in Fig. 3. The essential element of the setup consists of an air classifier. Observation of 
shredded waste segregation is possible as a result of the use of pipes made of transparent plastic. The selection of the material ensures the transparency in the observation plane.

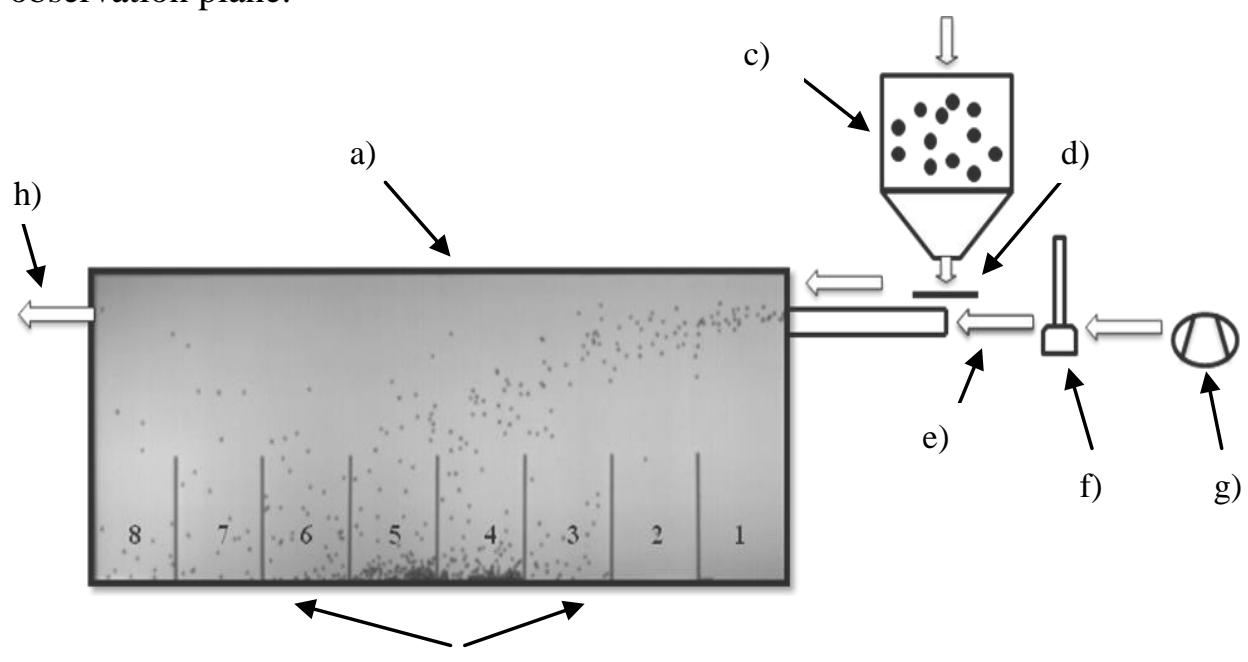

b)

Fig. 3. Diagram of the experimental setup: a) air classifier, b) collection area of shredded waste, c) waste reservoir, d) metering valve, e) inlet pipe, f) rotameter, g) compressor, h) outlet pipe

The air classifier placed on a rack contained at its bottom a separation tank divided into equal areas of shredded waste collection, as presented in Fig. 4. A waste reservoir was installed at the top of the air classifier and included a valve to measure the volume of waste feed. Air feed from a compressor was applied to carry waste through the inlet pipe. The measurement of the regulated volume of air was made by a rotameter.

The observation of the segregation was performed with a high-speed digital camera, and balls made of ceramic material were used as the shredded waste. The obtained images of the segregation were saved in the form of monochrome bitmaps. 


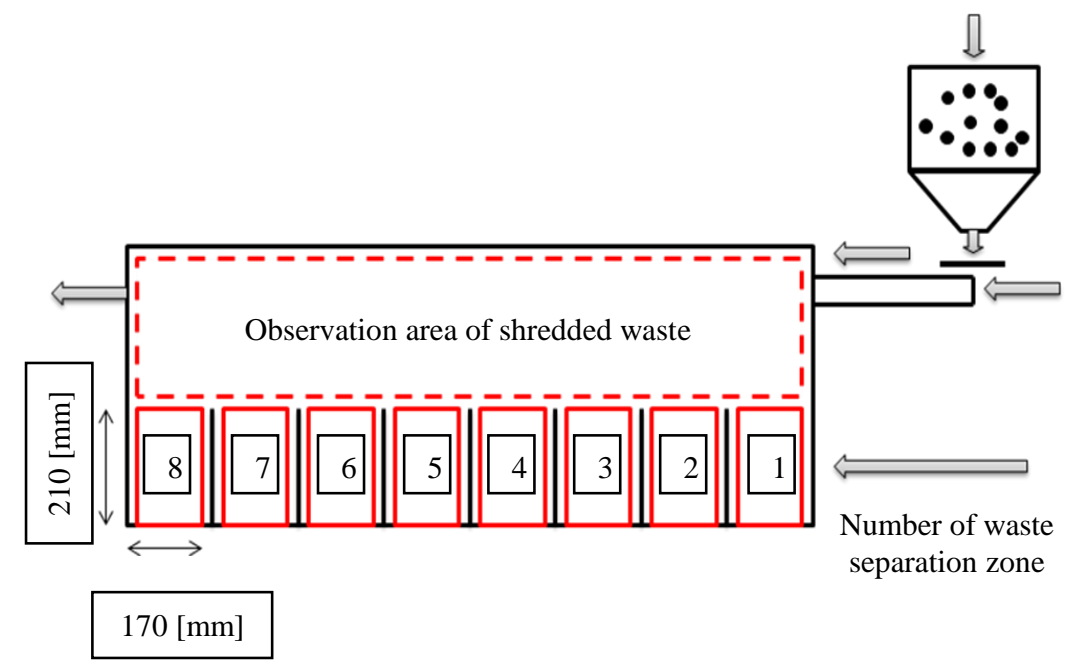

Fig. 4. Areas of separation tank into waste separation field along with an indication of the observation zone of shredded waste

\section{RESULTS}

On the basis of the experiment it was possible to present the results of the analysis of velocity field vector of sorted shredded waste in an air classifier. The calculations were carried out with the assumption of the application of solid particle to be markers in the stream of air including shredded waste. The interval between the registered images of segregation and scale coefficient [1] were applied to be the parameters defining the movement of shredded waste. The recording time resulted directly from the parameters of the camera while the width of the collection area (i.e. place where the sorted waste was collected) was adopted to be the scale factor.

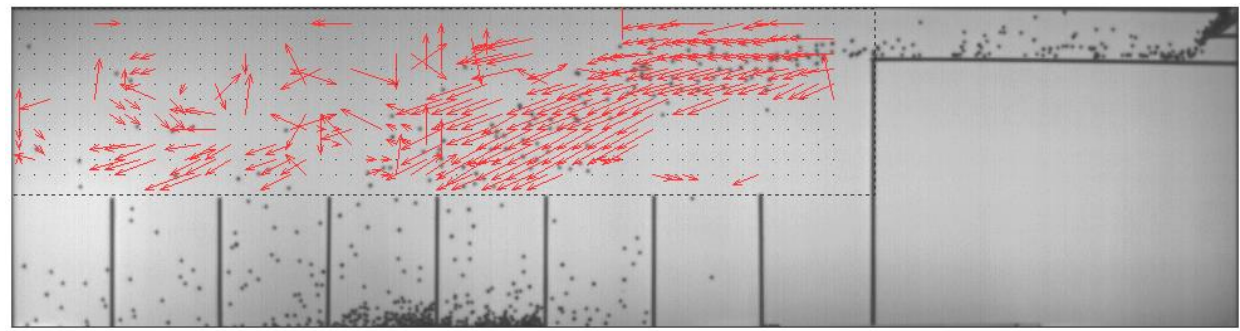

Fig. 5. Vector velocity field shredded waste segregated in air classifier 
On the basis of the comparison of the velocity vector fields during segregation of waste in the air classifier it was necessary to pay attention to the directions and senses of the vectors. The characteristics of velocity sections can be derived from the visualization of the vector field. Adjacent vectors with high compatibility with each form the first zone, while it is usually characteristic of the area of the initial section of the air classifier. This may be due to the dominant characteristics such as mass or size shredded waste at the entry of the air classifier. The second zone is formed waste by waste with non-uniform areas of distribution in terms of directions and sense vectors which result from the waste flipping and hitting the barrier, as it leads to subsequent disorganized waste movement. The result of vector incompatibility can be caused by very close distance barriers between individual areas of waste reception The minimization of the areas of non-uniform distribution of the collection zones is therefore important for the improvement of the efficiency of separation. Similar areas can be found in the final section of the air classifier. In addition, in this area one can note the smaller velocity of waste drop compared to the initial section, in which case after the opening the waste has to face airflow heading towards it. Single vectors with an opposite sense can also be seen in the area of observation, which may be due to inaccuracies during calculations.

When analyzing the velocity field vector of segregated waste, individual areas of the receipt were identified for the selected velocity profiles, as presented in Fig. $6(a-c)$.
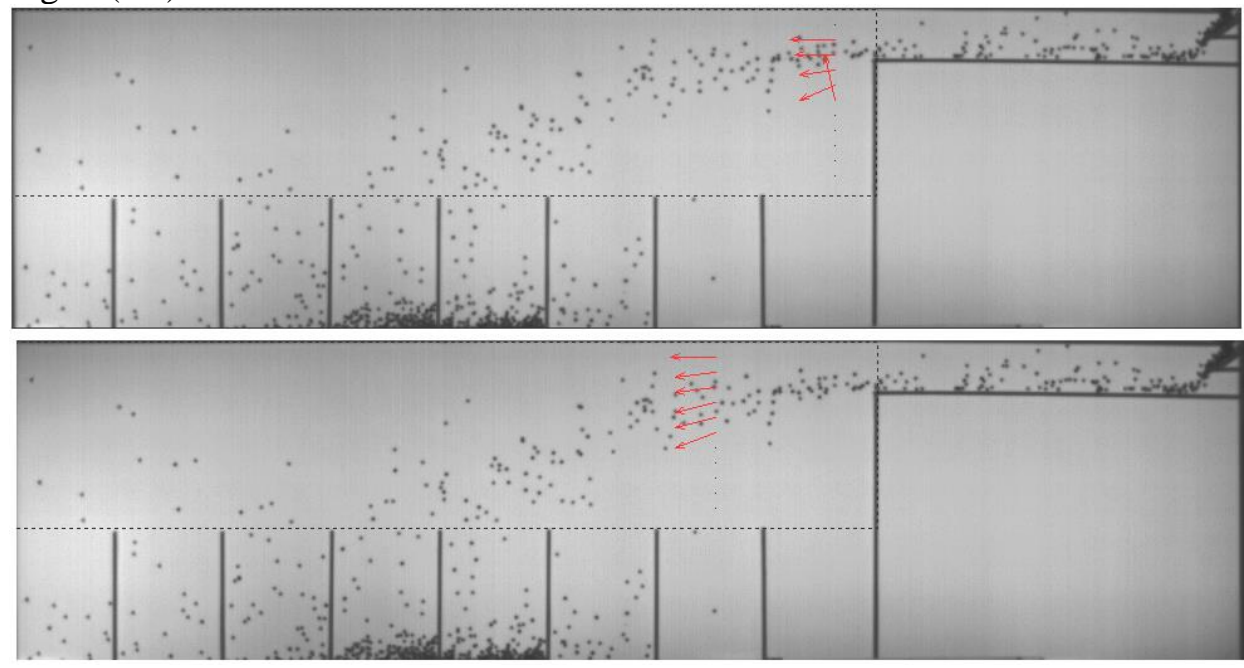

Fig. 6a. Velocity profiles of shredded waste segregated in different collection areas in the air classifier 

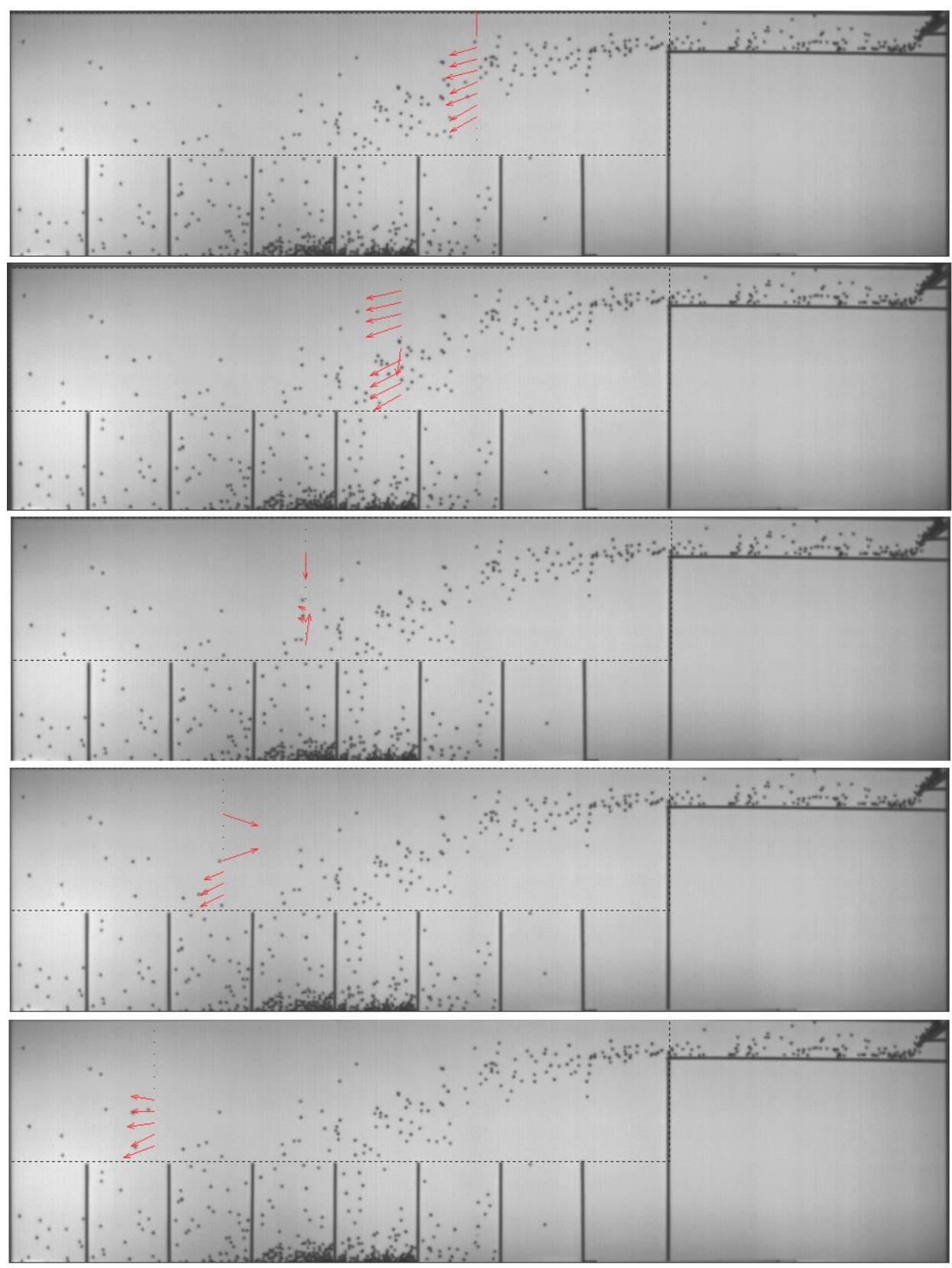

Fig. 6b. Velocity profiles of shredded waste segregated in different collection areas in the air classifier 


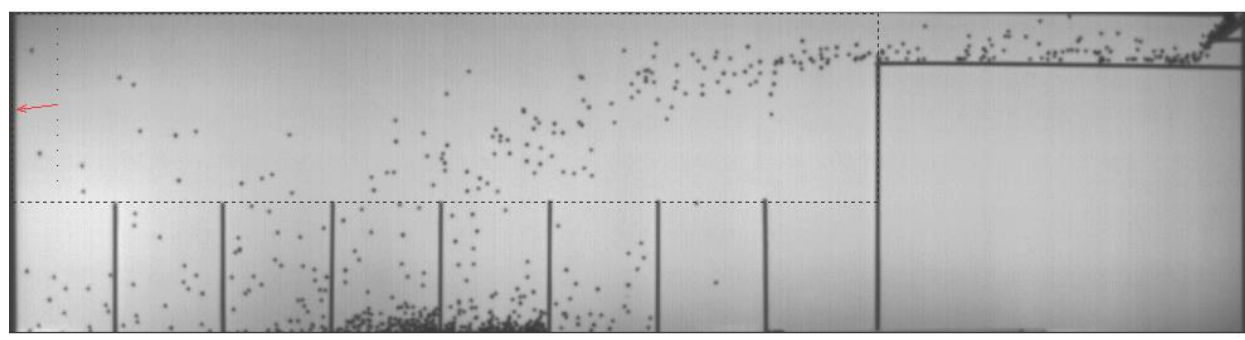

Fig. 6c. Velocity profiles of shredded waste segregated in different collection areas in the air classifier

It was noted that there is a possibility of describing segregation of shredded waste on the basis of the distribution of velocity profiles for each of the individual zones of shredded waste collection. The correlation for each reception zone along with a description of the velocity vector profiles offers the possibility of describing the phenomenon of waste segregation. The determination of the directions and senses of the velocity vectors which form the cross-sectional velocity profile for each of the individual areas offer the representation of the phenomenon of waste segregation. Thus, it is possible to obtain images of moving markers (shredded waste) in respect to their behavior in the different sections of the installation.

The increase of the distance between the successive zones of reception in the distance from the inlet pipe of the air classifier results in a change in the relations between shredded waste segregation. This change is reflected in the distribution of components of the velocity profile for each reception zone. The biggest compliance in the directions and senses of the vectors was observed for the central zones of reception, which indicates that the segregation of the selected material (shredded waste) was successful. Hence, the shredded waste does not fall right at the beginning of the initial section and pass into the collection areas, but neither does it hit the wall at the end of the air classifier. It is therefore possible to determine the value for a given stream of segregated waste on the basis of the distribution of the velocity vector profile.

\section{CONCLUSIONS}

The paper discusses problems related to the increase of the effectiveness of operating air classifiers using the image analysis method. Based on the study, the conclusion can be made that the segregation of waste in the air classifier mainly results from the interactions between the particles during their fall. As a result of adequate selection of the image analysis method, it is possible to describe the phenomenon of segregation by means of the techniques offered by 
a digital camera. One of such techniques of visual determination of velocity vectors was applied in the tests which applied shredded waste segregation using image analysis. Satisfactory results confirm the applicability of the image analysis methods in the research of segregation of shredded waste. However, the analysis did not enable authors to define areas which affect the impairment of the efficiency of the air classifier.

The representation of shredded waste segregation in the device allowed the description of waste through air classifier to be made. The proposed description of the phenomenon of the shredded waste segregation based of recognizing the distributions of the profiles of velocity vector profile in the area of waste collection proved to be correct. On the basis of the proposed solution of image analysis it is possible to improve conditions so that the optimum operation of equipment is achieved.

\section{ADDITIONAL INFORMATION}

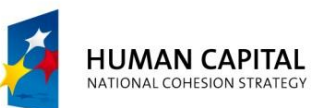

EUROPEAN UNION

EUROPEAN

SOCIAL FUND

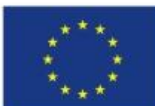

"Doctoral scholarships - investment in the scientific staff of the Opolskie Region"

\section{REFERENCES}

1. Bieńkowski G.: Zastosowanie cyfrowej anemometrii obrazowej do wyznaczania pól prędkości, Praca dyplomowa magisterska, Politechnika Warszawska, Płock 1999.

2. Byung-Hwan Chu: Experimental investigation of particle segregation in Hopper discharge 2008.

3. Grant I.: Selected papers on particie image velocimetry, SPIE Milestone Series MS 99, SPIE Optical Engineering Press, Waszyngton 1994.

4. Jain NF., Ottino J. M., Lueptow R. M.: Regimes of segregation and mixing in Regimes of segregation and mixing in combined size and density granular systems, An experimental study, Granular Matter, 7, (2005) 69-81.

5. Shapiro M., Galperin V.: Air Classification of Solid Particles: a Review, Israel: Chemical Engineering and Processing, 44, (2004) 279-285.

6. Smith S. W.: Digital signal processing. A practical guide for engineers and scientists, Elsevier Science, Burlington 2003. 
7. Swartzbaugh J. T., Duvall D. S., Diaz L. F., Savage G. M.: Recycling Equipment and Technology for Municipal Solid Waste, Noyes, William Andrew Publishing 1993.

8. Tadeusiewicz R., Korohoda P.: Komputerowa analiza $i$ przetwarzanie obrazów, Wydawnictwo Fundacji Postępu Telekomunikacji, Kraków 1997.

9. Tchobanoglous G., Kreith F.: Handbook of Solid Waste Management, New York, McGraw-Hill 2003.

10. Wodziński P.: Elementy składowe linii technologicznych do segregacji odpadów bytowych, Ogólnopolska Konferencja Naukowa Kompleksowe i Szczegółowe Problemy Inżynierii Środowiska, Darłówko 2007.

11. Wodziński P.: Metody segregacji odpadów komunalnych, Zeszyty Naukowe, Politechnika Koszalińska, Inżynieria Środowiska, Nr 22, 2005.

12. Zając D., Ulbrich R.: Nieinwazyjne metody badań przeptywów dwufazowych gaz-ciecz, Studia i monografie, z. 174, Politechnika Opolska, Opole 2005.

\section{WYKORZYSTANIE METOD ANALIZY OBRAZU DO SEGREGACJI ODPADÓW ROZDROBNIONYCH W KLASYFIKATORZE PNEUMATYCZNYM}

\section{Streszczenie}

Segregacja odpadów rozdrobnionych jest jedną z technologii gospodarki odpadami, obejmującą zagadnienia związane $\mathrm{z}$ segregacją ręczną, która została wzbogacona o klasyfikację pneumatyczną. W niniejszym artykule przedstawiono klasyfikator pneumatyczny oraz możliwości wykorzystania metod analizy obrazu do oceny segregacji odpadów rozdrobnionych. Tego rodzaju klasyfikatory pneumatyczne mają istotne znaczenie ze względu na sprawność urządzenia, a także charakter prowadzenia segregacji. Autorzy przedstawili wyniki badań dotyczących analizy obrazu segregacji odpadów rozdrobnionych w opraciu o wykorzystanie metod analizy obrazu.

słowa kluczowe: segregacja, odpady rozdrobnione, klasyfikator pneumatyczny, metoda analizy obrazu 